\title{
Intra-European Mobility of Skilled Expatriates and Place-Identity: Interwoven Social Representations of Rome and Warsaw
}

Movilidad intraeuropea de los expatriados calificados y la identidad de lugar: las representaciones sociales cruzadas de Roma y Varsovia

Annamaria Silvada de $\operatorname{Rosa}^{1} \&$ Laura Dryjanska ${ }^{2}$

\section{ABSTRACT}

This paper discusses the influence of social representations of a destination city on the motivation and development of individual mobility patterns, using questionnaires with a projective technique and guided interviews. The participants were 60 skilled expatriates in two different European capital cities: Italians residing in Warsaw and Poles residing in Rome. The study demonstrates the relevance of place-identity for the meaning of place within urban culture, in the context where global and local issues are interwoven. It also features the transformation of social representations of the two cities.

Keywords: 1. intra-European mobility, 2. skilled expatriates, 3. social representations, 4. Rome, 4. Warsaw.

\section{RESUMEN}

Este artículo discute la influencia de las representaciones sociales de una ciudad de destino en la motivación y el desarrollo de modelos de movilidad individual, a través de cuestionarios con una técnica proyectiva y entrevistas guiadas. Los participantes fueron 60 expatriados calificados en dos capitales europeas diferentes: los italianos que residen en Varsovia, y los polacos que residen en Roma. El estudio demuestra la relevancia de la identidad de lugar para el significado del mismo dentro de la cultura urbana, en el contexto donde los temas globales y locales están entretejidos, presentando también la transformación de las representaciones sociales de ambas ciudades.

Palabras clave: 1. movilidad intraeuropea, 2. expatriados calificados, 3. representaciones sociales, 4. Roma, 5. Varsovia.

Date received: June 16, 2017

Date accepted: February 15, 2018

Published online: July 30, 2020

\footnotetext{
${ }^{1}$ Sapienza University of Rome, Italy, annamaria.derosa@uniroma1.it

${ }^{2}$ Biola University, Rosemead School of Psychology, United States, laura.dryjanska@biola.edu
} 


\section{INTRODUCTION}

Can the term "temporary migration" be applied to the communities of skilled expatriates who move among the European Union states? With the free circulation of workers, the contemporary theoretical approach to mobility in this context has overcome "the old dichotomies of migration study, such as internal versus international, forced versus voluntary, temporary versus permanent, legal versus illegal"' (King, 2002, p. 89). In order to research this particular area of overlap, the statistical information available may not be of much help, or it may be misleading. Some individuals may choose not to change their formal residency status despite living outside their country of origin for a number of years; others opt for double residency status. Rather few studies have focused on the overlap between temporary and permanent skilled expatriates' mobility, and more research is certainly needed (Khoo, Graeme, \& McDonald, 2008).

Among the exceptions we may cite the study by Balaz, Williams, and Kollar (2004), which detected strong links between initial temporary migration and eventual permanent migration of young people from Central and Eastern Europe to the Western European countries. It seems that the neoclassical economic theory of international migration, which emphasizes high salaries and attractive employment opportunities as the main reasons for permanent mobility, is not sufficient to fully explain the motivations of communities of skilled expatriates (Khoo, McDonald, Voight-Graf, \& Graeme, 2007). While kin and social networks in many cases influence the decision to migrate (Massey, Arango, Graeme, Kouaoua, Pellegrino, \& Taylor, 1993), the lifestyle factor has been identified as a decisive motivation in Australia, especially in the case of skilled expatriates whose employment conditions and living standards in their country of origin were the same or actually better (Khoo et al., 2007). Taking the term "lifestyle" one step further on the theoretical level, it can be incorporated into the construct of "social representations," which are "ways" of knowledge peculiar to social reality that arise in daily life in the course of interpersonal communication and are aimed at the understanding and control of the physical-social environment" (de Rosa, 1993, p. 4).

The meanings of places, whether phenomenological, symbolic, or social constructivist (Janz, 2005), influence people's decisions to travel, as well as the way in which they perceive the attractiveness of a destination beyond purely economic factors. Especially in the case of skilled expatriates, who constitute a diverse and complex community (King, 2002), understanding their image of destination cities, their social representations, may shed new light on the motivation and development of individual mobility patterns. Detected social representations unveil the perceptions of urban reality, contextualizing it from within, and thus shaping behavior (Pricket, 2014). The social representations of places are relevant for the transnational identity of skilled expatriates when exploring their reasons behind mobility. 
In the conceptual framework of 'brain circulation' (Pellegrino, 2001), this paper discusses the influence of social representations of a destination city on the motivation and development of individual mobility patterns among the communities of skilled expatriates. The intra-European mobility is thus an interface of global and local issues, locally embedded social interaction, and community life. In particular, the focus is on the meanings of places integrated in the social representations of Rome among Polish skilled expatriates and the social representations of Warsaw among Italian skilled expatriates. The methodology used consists of a projective research instrument developed by de Rosa (1997) to define placeidentity and mobility patterns (1997; 2013a), as well as guided interviews analyzed with ALCESTE software.

This article consists of six parts. First, we present the theoretical background related to mobility of skilled expatriates, the theory of social representations, and the applications to urban contexts and place-identity. Second, we discuss the history and actuality of Rome and Warsaw as mobility targets. Third, the methodology section concentrates on the data sources, research instruments, and type of analysis. Fourth, we present a demographic profile of participants, following the explanation of how they were recruited. Fifth, the results are divided into two sections: place-identity and cluster analysis of guided interviews. This section already contains the discussion. Sixth, we present our conclusions in relation to the theoretical background.

\section{THEORETICAL BACKGROUND}

Iredale (2001) distinguishes three types of theories on professional migration: human capital theory with a micro-level approach, structuralist neo-Marxist theories with a macro-level approach, and the "structuration" perspective (Goss \& Lindquist, 1995). More recent theories of professional mobility include transnational feminism, highly related to postcolonialism (Pio \& Essers, 2014), which stresses how scattered gender hierarchies are emphasized through scattered transnational hegemonies (Cresswell, 2016), challenging western feminist theorizations of gender relations as furthering the images and social experiences of mostly privileged women in the "first world" (Calas \& Smircich, 2006). Goodson and Grzymala-Kazlowska (2017) point out that in the contemporary scenario of superdiversity, space/place is one of the dimensions. Understanding how places in general and cities, in particular, are represented by societies, especially by their skilled and educated communities, affords additional insight into the phenomenon of mobility. This is evident from the following contemporary definition of a city, which highlights four characteristics (Marada, 2011): 1) expanding, bound to grow in terms of population and territory, 2) political and economic importance, 3) education and culture, and 4) mobility target.

Originated from Serge Moscovici's 'Opera Prima' (1961), the theory of social representations, originally European, is currently a multilingual worldwide field with a 
substantial body of literature in social psychology and other social science. Studies of "what" people know -and "how" this laypeople knowledge relates to the social groups to which they belong and are shaped by the polyphonic traditional and new media system- are concerned with the social construction of everyday knowledge and the related socially situated practices (de Rosa, 2015, p. 260). The "objects" studied have a strong societal impact in all the spheres of the social arena (de Rosa, 2013b).

The supra-disciplinary application of the theory of social representations in this research includes not only migration studies but also environmental psychology. According to de Rosa (2013a), environmental social psychology deals with pressing social-environmental problems while raising pertinent theoretical questions about social psychology itself. Inspired by the theory of social representations, this research appreciates the socio-normative and cultural-symbolic aspects of the environment (Castro, 2006). Jodelet (2008, p. 419) states that social representations "are considered as meanings; they express group dimensions as well as cognitive and symbolic ways of naming and classifying social reality and coping with unfamiliarity," while providing a new reflection on diversity in forms of knowledge. In the supra-disciplinary context, social representations are therefore characterized by "the interdependence, actual or symbolic, of a plurality of subjects in their relation to a common environment, be it of a physical or social nature" (Moscovici, 1970, p. 33).

Over the years, numerous authors have studied social representations of places in urban contexts (Jodelet, 1987; de Rosa, 1995, 1997, 2013a; de Rosa, Antonelli \& Calogero, 1995; de Rosa \& d'Ambrosio, 2011; de Rosa, Bocci \& Picone, 2013; de Rosa \& Bocci 2014). Social representations of different places in the city are mutually interdependent and form "a naïve theory of the city" that enables organization of the surrounding urban reality, orientation within it, and communication with other inhabitants in its regard (Bonnes \& Secchiaroli, 1995, p. 183). In fact, the theory of social representations is widely applicable to social issues and in particular to the migration phenomenon, as well as the urban design (Hubbard, 1996). According to Rateau, Molinier, Guimelli, and Abric (2011), its applicability is due to the following three characteristics: it is an adaptable and versatile theory; it is a common-sense psychosocial theory; it has given rise to various methodologies. The theory of social representations has been defined as a useful heuristic tool for the comprehension of settings (Fuhrer, 1990; de Rosa, 2013b) conceived not only as physical places but also as dynamic relationships between people and groups (Bonnes \& Secchiaroli, 1995). Paiva (2016) points out that in the urban context the modulation of senses, such as danger or vitality, stems from social representation of places. We argue that thanks to the above characteristics, the theory of social representations provides an appropriate, articulated framework in which to investigate complex aspects of skilled intra-European mobility in an urban context. 
What is the relationship between social representations and international mobility? Experts in the field have applied the theory of social representations to a variety of aspects of mobility throughout the world. Andreouli and Howarth (2013) have considered the role of both State and society in the construction of migrant identities in Great Britain. Discussing her interviews with Polish migrants in Ireland, who are away from their home countries and come to terms with a new social reality, Kempny (2013) has concluded that social representations equip them with a sort of safety net. Orr, Mana, and Mana (2003) have applied the construct of social representations to the study of successful adaptation to Israel (klitat aliyah) of adolescents from Ethiopia and the former USSR.

In China, Guan and Liu (2014) have explored the stigmatization of rural-to-urban migrants using the social-psychological framework of the theory of social representations to study the circulation of common-sense knowledge. Fazito and Soares (2015) have laid the theoretical foundation for their analysis of the Brazil-U.S. mobility system by conceptualizing Tilly's notion of a migrant as a "self-made man" (Tilly, 1990), as a social representation. In the context of international mobility from Ecuador, Boccagni (2013) has applied the theoretical perspective of social representations to reflect upon the widespread view of mobility as "a major social illness" in light of family transformations.

Applying the perspective of social representations to the construct of place-identity in the context of mobility is to use an original conceptual framework that serves to identify critical dimensions of difference between the city cases and between and within communities, comparing the experiences of skilled expatriates in Warsaw and Rome. According to de Rosa (2013a), the theoretical construct of place-identity is an interesting heuristic object in this supra-disciplinary field because of the links that it implies among the study of places, social representations of the environment and its social memory, and various theories of the self. This construct is shaped over time, "through interactions that create values and beliefs" (Anguelovski, 2013). De Rosa (2013a, p. 316) has defined place-identity as a "substructure of self-identity characterized by clusters of cognitions, memories and affects concerning places experienced by the individual. It is an active personal construction, deriving from day-to-day experience of the physical environment mediated by subjective meanings and social norms, and characterized by the formulation of hierarchically organized and structured cognitions of the physical-social settings experienced." The consideration of space and location, in particular in the context of cities has been recognized as a significant theme in the study of mobility (Kraly \& Hirschman, 1994).

The role of social positioning as a link between identity and social representations (Elejabarrieta, 1994), is fundamental even when examined from the perspective of the identity theory (ITP) proposing that the "individual's identity is a dynamic social product of the interaction of the capacities for memory, consciousness and organized construal with the physical and societal structures and influence processes which constitute the social context" (Breakwell, 2010, pp. 6-3). 
In the case of communities of skilled expatriates, the dynamics between identity and representations become essential, while paying attention to place-identity is crucial in order to understand their relationship with the city. The perspective of transnationalism makes room for the discussion of multiple self-identification with respect to a place, in particular a home, as emphasized by Cresswell (2014).

\section{ITALY AND POLAND AS MOBILITY CONTEXTS}

This paper discusses the diverse experiences of communities of skilled expatriates in the cities of Rome and Warsaw. Why these two cities? Rome could be classified as a global city (Hodos, 2007). It has a long history as a destination for the Polish elite. Historically, the Polish nobility traveled to Rome for religious and educational purposes. Hence, although there were no large-scale movements, we may speak of an emerging trend of mobility of the political elite. Worth mentioning is the period called the 'Great Emigration' by Polish historians, which began after the insurrection of 1830-1831. At that time, when Poland was erased from the political map of Europe, numerous intellectuals, politicians, and artists (mainly painters, poets, and writers) spent at least some time in Rome, which inspired and influenced their art, thus leaving a lasting imprint on Polish culture. Although they should rather be called 'exiles' (Zubrzycki, 1953), the term 'emigrants' has described them until today, and throughout the history of Polish mobility, a prototype of emigrants who rescued the national identity by moving away from the oppressed homeland is present in Polish imagery.

In recent decades, Rome's 'magnetism' has been reinforced by the elevation of a Pole as Pope John Paul II in 1978 and as a saint in 2014. Therefore, Rome has historically been a second home for Polish elites, so that the large Polish presence in Rome still today should not be surprising, also after Poland's entry into the European Union. Before this event, Italy was the third largest mobility destination in the world and the second in Europe, following Poland's close neighbor country Germany. However, the trend has recently changed, and for purely economic reasons the United Kingdom appears as the most attractive country to Polish workers who decide to leave their homeland (Iglicka \& Ziolek-Skrzypczak, 2010).

On the other hand, Warsaw fits quite well the definition of the second city (Hodos, 2007). Mobility to Poland has never been significant, although in recent years the country's membership to the European Union is beginning to change the situation. In particular, a city like Warsaw attracts Italian skilled expatriates, especially entrepreneurs, due to lower costs and more incentives for business start-ups, interesting sources of financing, such as European funds, as well as numerous other factors discussed in this paper. These persons would not refer to themselves 'immigrants' since in Italy this term carries negative overtones, and they do not perceive their residency in another country as migration. Since it is a fairly frequent practice in contemporary scientific literature to refer to skilled expatriates 
(Cranston, 2017; Kunz, 2016; McNulty \& Selmer, 2017), also respecting this label as preferred by the participants (McHenry \& Welch, 2018), in this paper we opted for this term rather than migrant.

According to the Italian Ministry of Interior, the total number of Italian residents in Poland as of 2015 was equal to 4,634 (Ufficio Centrale di Statistica, 2016). The number of Italian residents has been growing in recent years, with a higher percentage of male newcomers, reaching a total of 387 persons registered at the Italian embassy in Warsaw until 2012. Skilled expatriates constitute close-knit communities who organize numerous events and activities. Although the numbers are not extremely high, the daily lives of these communities in the urban context constitute a worthwhile research focus, which accounts for the narrative complexity without reducing the cities to their epochal characteristics (Beauregard, 2003, p. 190).

\section{DATA AND METHODS OF ANALYSIS}

The two cities chosen for this research constitute an interesting and relevant example of contemporary Europe, including their different geopolitical history. At the same time, the skilled expatriates are in a position of providing articulate accounts of their experiences in a guided interview. Their knowledge of the urban contexts and capacity of informed selfreflection may give insight into the intrincacies of the interplay of motivations, placeidentity, and social representations of cities. According to van Riemsdijk (2016), the creation of place-identity operates differently in less iconic destinations (such as Warsaw), which makes the comparison of these two contexts worthwhile.

In order to gain a deeper understanding of the participants' place-identity, we employed the projective research instrument developed by de Rosa (1997; 2013a), which enables identification of the importance attributed to different experienced life stages, as well as important places in each experienced life stage, thus capturing the mobility patterns. For the five life stages - childhood, adolescence, youth, maturity, and old age - participants were asked to attribute importance to each one of them that they had experienced or were currently experiencing and to enlist places meaningful to them during those periods, using open space. The places were categorized after data collection by two independent judges. No age limits were given to define life stages, but the categories corresponded to the participants' common-sense understanding. In line with the assumptions of the theory of social representations (Collins \& Shubin, 2015) and the changing social construction of age (Mortimer \& Moen, 2016), we opted for the subjective, self-declared view of each person, considering individual trajectory and system of meanings.

The analysis of the guided interviews was performed using the ALCESTE (Analyse Lexicale par Contexte d'un Ensemble de Segments de Text, designed by Max Reinert) software package based on the descending hierarchical classification method. The interviews 
were all carried out in the participants' mother tongues, transcribed, and translated into English.

The questionnaire included demographic information about the participants (age, nationality, gender, and occupation). It also included a multiple-choice question concerning the reason for mobility to Rome or Warsaw (work, family, personal, and other - to be specified). The temporal axis with the range from 0 to 100 was used to measure place identity. On this line, the participant freely drew the life stages, instructed to make the more important ones longer, and the less important ones (in his or her subjective view) - shorter. Then, for each life stage, they had to enlist the most important places.

Guided interviews were audio-recorded and included the following questions: 1. How would you describe the reasons for your presence in Warsaw/Rome? 2. Please give me a brief description of the city. 3. What was your impression of the city at the beginning of your stay? 4. What is your impression of the city right now? 5. Altogether, what is your evaluation of the city? 6. What itinerary would you recommend to a friend who is for the first time in Warsaw/Rome?

Therefore, we obtained both quantitative information from the multiple choice questions, as well as qualitative data from free responses to open questions.

\section{PARTICIPANTS}

The participants were recruited using a snowball technique based on information from official sources, such as the respective embassies and consulates, chambers of commerce, national cultural institutes abroad, associations, Polish churches in Rome, and Italian churches in Warsaw. All of these constitute points of reference and aggregation to the expatriate communities.

The main criteria used to select the participants were higher education, socio-economic status (white-collar workers only), and length of residence in the foreign city. Overall, sixty skilled expatriates took part in the research, equally distributed between Italians and Poles. $55 \%$ of all participants were female. The average age of Italian participants was 44 , while for the Polish ones it was 42, with the youngest participants aged 26 and 20, and the oldest ones aged 71 and 73, respectively for Italy and Poland.

The initial motivation to move to the new city (see Figure 1) was predominantly work, for both Italian and Polish participants. Family reasons were the second most important motivation, especially for Poles, in most cases specified as marrying an Italian. Personal reasons included diverse situations, from avoiding legal problems to seeking a less chaotic place to live (in the case of Italians) or, on the contrary, a more exciting one (in the case of Poles). A few Poles also evoked "tourism" as initial motivation, recalling the communist era 
when tourism was also a way to escape from the regime and/or an occasion to discover a new homeland in which to live freely and with more opportunities and material goods.

Figure 1. Reason for Moving to the City

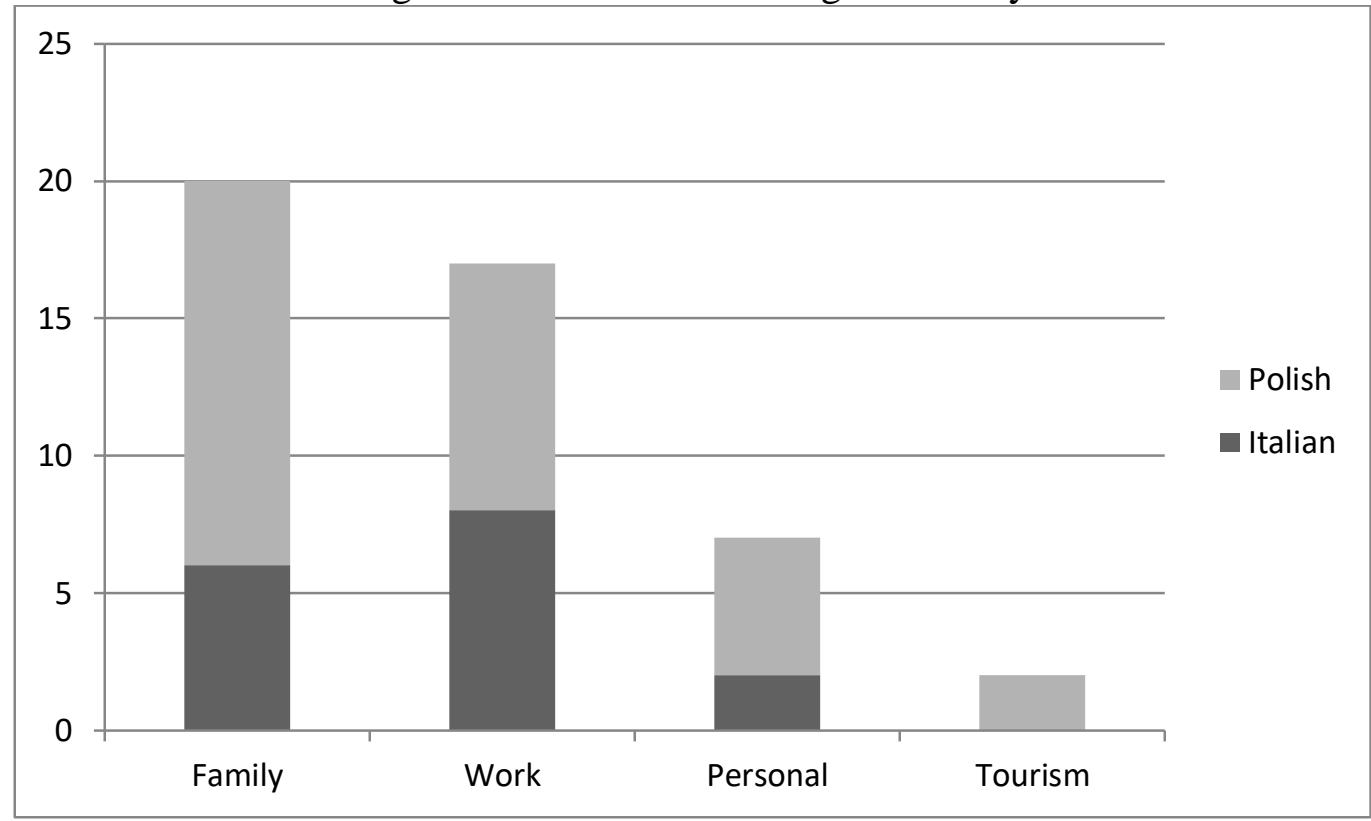

Source: Author's own figure based on replies to questionnaires of 60 skilled expatriates (Italians residing in Warsaw and Poles residing in Rome).

The occupations of the interviewees demonstrate that the research focused on skilled expatriates. The majority of the Polish residents in Rome worked in diplomatic settings, while the majority of the Italian residents in Warsaw owned a business in Poland. The rest were professionals: journalists, academics, lawyers, and doctors. These groups of professionals constitute communities, the participants know one another and are linked by both work-related and personal ties.

\section{RESULTS AND DISCUSSION}

The results demonstrate the distinctive nature of mobility by the communities of skilled expatriates as neither temporary nor permanent. In line with the theoretical assumptions of transnationalism, multiple self-identification often occurs among skilled expatriates in respect to places (Cresswell, 2014). Since their financial conditions allowed it, our participants often possessed land and goods both in Poland and in Italy; they traveled between the countries several times a year; they worked in one country while being paid in the other; they had relatives in both countries trying to overcome some of the legal obstacles to intra-European mobility (Peixoto, 2001). 


\section{Place-Identity on the Temporal Axis}

The analysis of the temporal axis demonstrated that, within the range from 0 to 100 , both Italian and Polish participants attributed the greatest importance to their life stage of maturity; however, for Poles, their youth was almost as important as their maturity (and also adolescence was evaluated as more significant than among Italians), while for Italians the second most important period was their old age, as shown in Figure 2 below.

Figure 2. Average Importance of Life Stages by Nationality

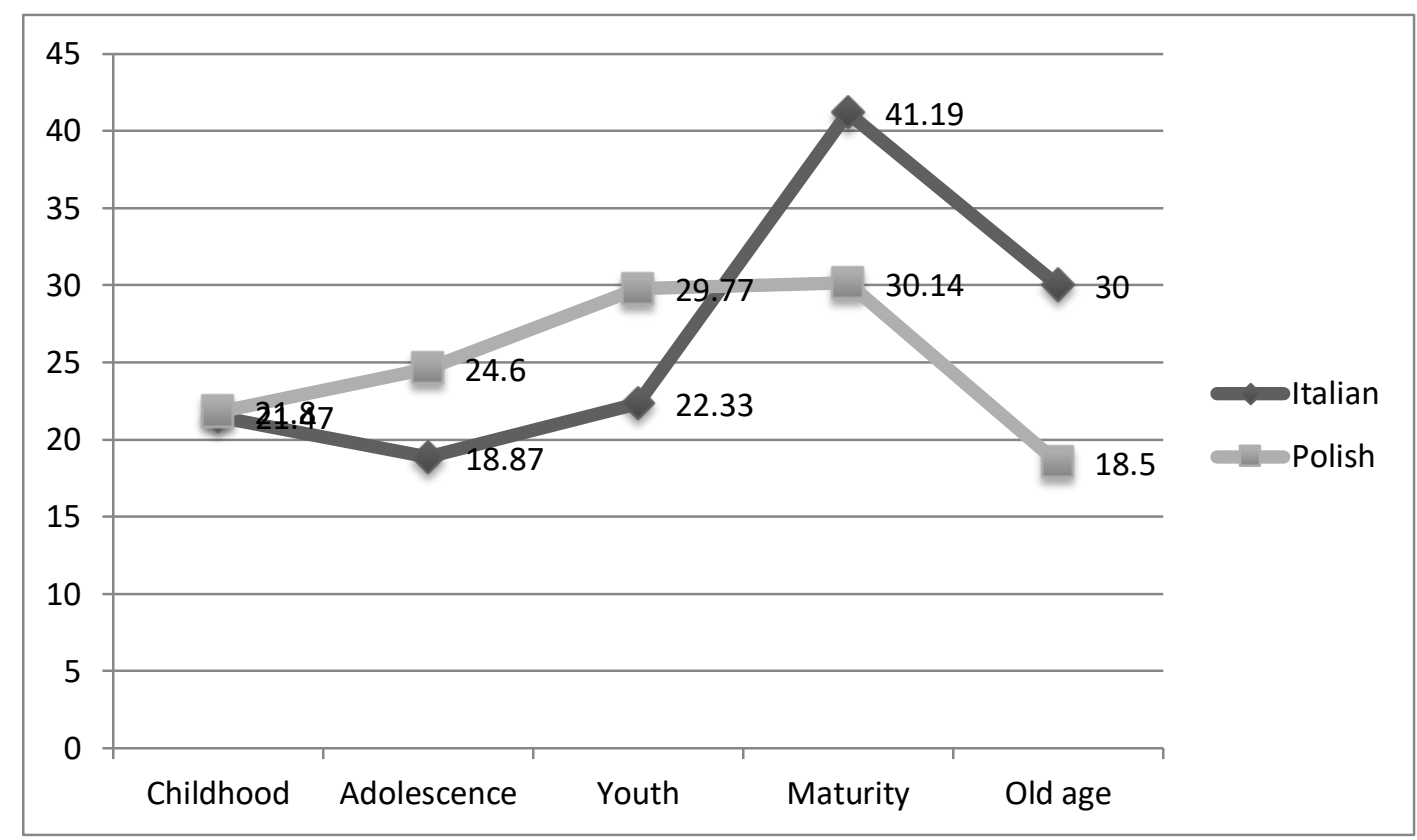

Source: Author's own figure based on replies to questionnaires of 60 skilled expatriates (Italians residing in Warsaw and Poles residing in Rome).

This stress on current aspects of life may indicate a willingness for continuous mobility between important places in life (since the present appears more important than the past and is characterized by mobility). According to Ackers (2005, p. 110), "the temporal nature of scientific moves may vary both between individuals and over the life course and career trajectory."

Concerning types of places, the participants who belonged to the Italian community overall most frequently mentioned places related to "nature" especially important to them during their childhood and adolescence. During youth, the most important places mentioned were related to the participants" "workplace," while during maturity the greatest importance was given to "cities" and "countries." Very few places were mentioned for old age. Polish expatriates in Rome most frequently mentioned "cities" and "countries," overall and during youth, maturity, and adolescence. Places related to nature were decidedly the most important to them during childhood, while for adolescence the most frequently mentioned places were 
related to school. In general, Italians seemed to focus more on school, entertainment, nature, vacation, and recreational spaces, while Polish participants focused more on home (parents and own), meeting points, and cities and countries. This may indicate different place-related representations about sociality (Polson, 2015; Wise, 2016; Wladyka \& Moren-Alegret, 2014).

When asked about the single most important places in their lives, the majority of Italian participants mentioned "school and related places," immediately followed by "domestic environment," "cities" and "countries" and "entertainment." Polish participants considered "cities" and "countries" as the most important places, followed by their "parents' homes." As hypothesized, home-related places as a whole (including "own home," "domestic environment," "parent's home," "relatives' home") were important for all participants, as in the first wave research conducted in the city of Rome (de Rosa 1997; de Rosa, Antonelli \& Calogero 1995), which can be seen in Figure 3 below.

Figure 3. The Most Important Places in Life

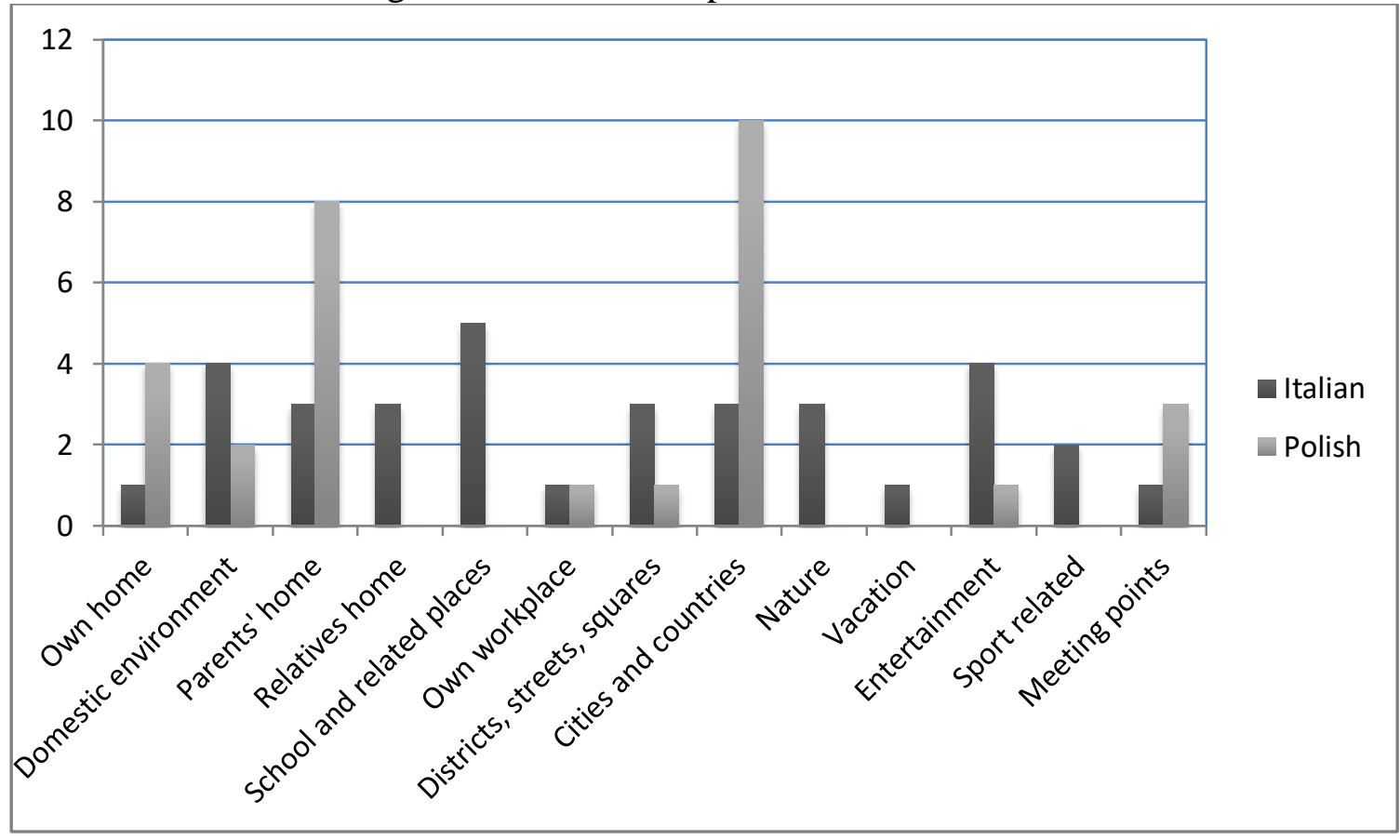

Source: Author's own figure based on replies to questionnaires of 60 skilled expatriates (Italians residing in Warsaw and Poles residing in Rome).

For all participants "home" was a heterogeneous object of identification and attachment for place-identity, including their own home, parents' and relatives' homes, as well as their home/host cities and countries. The borders between temporary and permanent migration blur as skilled expatriates find themselves traveling frequently between two homes in the transnational scenario of increasing superdiversity of today's Europe. 


\section{Guided Interviews: Cluster Analysis}

The textual corpus resulting from the transcription of the interviews translated into English retained $80.33 \%$ of elementary context units after the classification. Seven clusters, each characterized by its specific vocabulary, tool-words, and descriptive variables are shown in Figure 4 below in descending hierarchical order ("uce" denotes elementary context units). As regards the number of elementary context units, the highest number characterizes clusters 1 and 4, followed by clusters 2 and 3, while the lowest numbers characterize clusters 5, 6, and 7. Thus, the overall structure of the dendrogram is divided into two main groups. The first group, much more complex, contains the subgroup of clusters 4 and 5 that are connected with cluster 1. In turn, this subgroup is connected with clusters 6 and 7, forming the first group. The second group consists of clusters 2 and 3.

Figure 4. Dendrogram with Seven Clusters in Descending Hierarchical Order

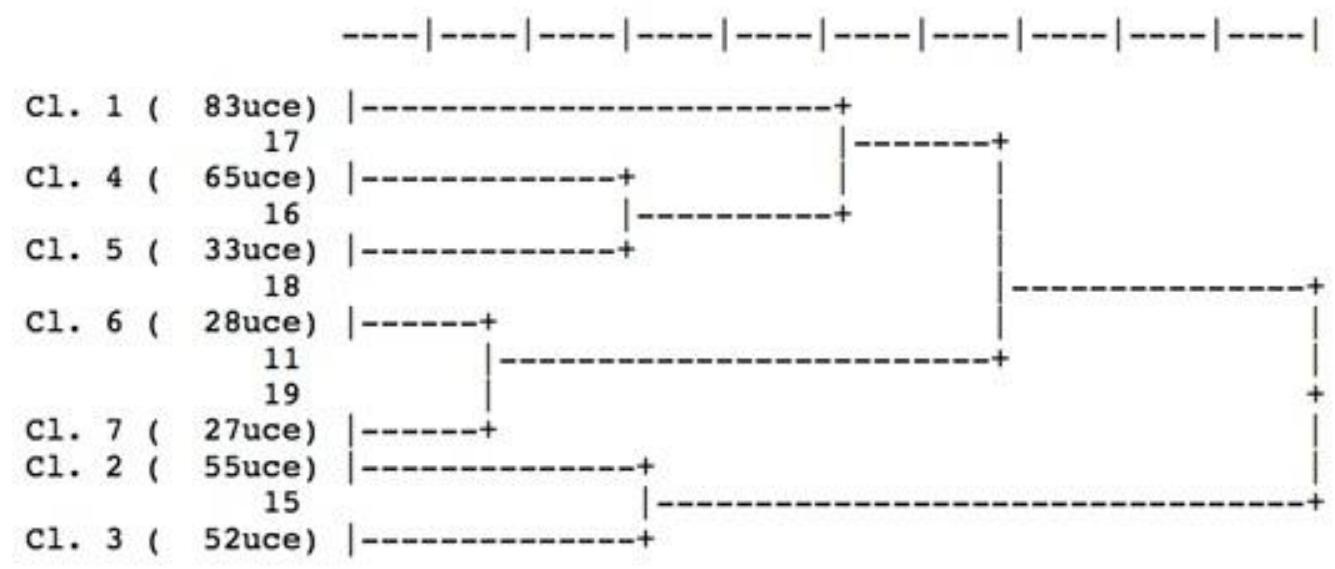

Source: Author's own figure based on the ALCESTE software output.

Based on thorough consideration of all the information that ALCESTE furnished for each of the clusters, they were named and interpreted on the basis of lexemes presented in alphabetical order, the specific vocabulary, the instrumental words, the illustrative variables, and the typical elementary context units that helped contextualize the lexemes.

The dendrogram presents all seven clusters, how they related to each other, which city or cities they described, and what percentage of all elementary context units (uce) they represented. There are two groups of clusters: the first and much larger group, interpreted as "More than meets the eye," contains five clusters $(1,4,5,6,7)$ that describe, evaluate, and judge the city/ies; while the second group of clusters $(2,3)$, interpreted as "The truth is hidden in the place," is focused on places.

The first cluster (1) focused on the characteristics of the inhabitants of Warsaw and contained $24.20 \%$ of all elementary context units. It described on the one hand young people, who were seen as dynamic, international, and well educated, and on the other hand some 
inhabitants who lived in thrall to Warsaw's tragic history, especially communism and war. The vocabulary specific to cluster 1 contained words describing the inhabitants of Warsaw ("Poles," "Polish"), in terms such as "young," "international," "different," "sad" or "communist." It compared (as evident from the repetitive use of the word "compared") Warsaw with known Italian cities (in particular "Milan" and "Turin"). Cluster 1, which we interpreted as "Human DNA of the city," was a reasoned evaluation of the personality traits and abilities of the inhabitants from the point of view of professionals (businessmen and journalists), people who had lived in the city for a long time (11 to 20 years), Italians, males, and subjects who had decided to marry someone of a nationality different from their own (Italian and Polish).

This condition justified lengthy and thorough descriptions of people in Warsaw, probably often seen as potential workers or collaborators. First, concerning professional aspects, this cluster highlighted the ability of the inhabitants of Warsaw to adapt skillfully and rapidly to the new democratic conditions, especially in the case of young people. Seriousness, hard work, and willingness to study (among other things, foreign languages) were pointed out as positive traits of a population doing all it can to make the city a truly European capital. Second, the people of Warsaw were seen as sensitive and artistic ("I have met poets, painters, musicians"). It was highlighted that Warsaw differs from the rest of Poland because of the outstanding characteristics of a culturally attractive European city. Third, the interviewees gave some thought to how Poles consider Italians, especially in the case of personal relationships. Speaking from his experience as an Italian husband of a Polish woman, one of the participants described an initial lack of trust ("Italians are considered conquerors of Polish women who then take them to Italy"), which he was able to overcome with time ("grandparents have always been helpful"). Fourth, there was also a focus on the personal traits of the inhabitants of Warsaw, seen as sad and reserved ("even young people open up only after certain situations, not immediately, because initially they are distrustful and maybe only after a drink together they begin to open up more"), as well as religious ("religion has influenced the character and the attitude of Poles"). This cluster investigated the human component of the city of Warsaw, the characteristics of its inhabitants, and the reasons why people act in a certain way.

The second cluster in the hierarchical order is cluster 4, which concerned impressions of the cities of Warsaw and Rome and contained $18.95 \%$ of all elementary context units. It comprised evaluations based on relative values - what is clean to one person appears dirty to another, while what one finds interesting seems boring to another. Practical aspects of daily life seem important for the overall impression of the city, with an especial focus on traffic, functionality, and weather. The values are not necessarily understood in positive terms, but also frequently as negative values; each person sees the surrounding reality of the city in a different light, based on their value system, personality, social position, culture, needs, priorities, etc. Different aspects were often also pros and cons of living in a certain 
city, a mixture of positive aspects, such as beauty for Rome or a high level of security for Warsaw, and negative aspects, such as inadequate public transport and chaos in Rome or cold winters in Warsaw. This cluster contained replies to such questions as the first impression of the city, current impression of the city, and overall evaluation of it.

Cluster 4 revolved around the impression and evaluation of the city. The most outstanding meaningful words (with the highest Chi2) were "aspect," "impression," "evaluation," "traffic," "opinion," "chaotic," "clean," "difficult," "worse," etc. Personal judgments were applied to both Rome and Warsaw, although Rome seems to be mentioned more often in this cluster, as demonstrated by the selection of elementary context units. Poles living in Rome focused on functional aspects of the city, which in their opinion is not easy to get around due to the traffic, chaos, and demonstrations. Some of them also found the city to be dirty, crowded, and dangerous. The Polish expats used comparisons with the past, seeing either improvement or deterioration ("it's worse every year," "always dirtier"). Different features cannot be all negative so that positive aspects of Rome were also mentioned: "warm impression," "it is a very beautiful city," "it has this charm."

In regard to Warsaw, the functional dimension similarly appears to be important - the city was considered well maintained and safe, as evidenced by these descriptions: "taxes in Poland and in Warsaw are way lower," "Warsaw has a high level of security." These impressions and evaluations of the cities, which cluster 4 interpreted as "Different rays of sunshine," were made by the youngest group of expats and those aged between 51 and 65, therefore those at the very beginning of their careers and those at the end of them. Moreover, research participants with the shortest duration of stay in the city (up to a year), as well as those who identified themselves as diplomats, doctors, and academics, who had a spouse of the same nationality as their own: each of these groups was the illustrative variable significant for this cluster. Different "rays of sunshine" on the city painted a personal picture consisting of meaningful experiences, both positive and negative, specific to each person, but also shared, especially in regard to the traffic in Rome. This cluster, containing the pros and cons of lives in both Rome and Warsaw, depicts a sincere effort to convey a personal experience based on past and current impressions of each city.

Cluster 5, interpreted as "At a first glance," presented impressions not backed up by experience and not thought through. It tried to capture the superficial outlook, especially the first impression of the cities, both Rome and Warsaw. When speaking freely about the city, the skilled expatriates inevitably shared their motivation for moving to live in a foreign city. Cluster 6 focused on Warsaw, in particular on the reasons that had induced the Italian interviewees to live there. They shared a story of transition to a new environment, not only a new city but also a new country and a new culture that most of them had chosen to get to know and to share to a certain degree. The cluster simply interpreted as "Why Warsaw?" presented different reasons inducing highly qualified professional Italians to move to that city. 
As a sort of a mirror, while cluster 6 contained motivations for moving to Warsaw, cluster 7 contained motivations for moving to Rome. When asked "Why Rome?" Polish skilled expatriates also mentioned professional and family reasons. However, cluster 7 included brief descriptions of the city of Rome seen through the eyes of Polish participants, because there was often a smooth passage from considering the reasons for moving to the city to describing the first impressions of it.

The five clusters described above referred to descriptions of the cities, focusing on more than meets the eye: personal impressions, experiences, human relations, pros and cons of daily life, etc. The two remaining clusters had a different focus - places. In particular, cluster 2, interpreted as "10,100, 1000 places," concerned specific places in Rome and Warsaw. Places to visit both in Warsaw and Rome were numerous and diverse. One can distinguish certain types of answers among "10, 100, 1000 places," some common to both cities, others specific to only one of them. In the cases of both cities, many of our research participants recommended visiting parks and green spaces, such as Lazienki Park in Warsaw or Villa Borghese in Rome. While in Warsaw parks are popular for artistic reasons ("summer concerts of Chopin, out in the open at Lazienki Park") and historical ones ("I would take a friend to famous parks or royal residences because they demonstrate the grandeur of the history of Warsaw"); in Rome, parks were seen as making it possible to admire the panorama of the city from a hill ("I would advise everyone to start their visit in Rome by climbing on top of one of the hills that has a view over all Rome or most of it").

Other types of places mentioned included neighborhoods, with special attention to fashionable districts especially popular with young people. In Warsaw, Italian skilled expatriates mentioned Praga, a neighborhood that used to be considered dangerous and rather run-down but has recently become an area with many clubs, alternative theatres, and trendy bars. Although Praga could not be found in most official guidebooks at the time, foreign residents in Warsaw appreciated it and would recommend it to their friends ("for example Praga, not very well known and not properly valued by Poles themselves"). Similar types of neighborhoods were recommended by the community of Polish skilled expatriates in Rome, who found Trastevere and San Lorenzo fascinating ("I would definitely recommend the San Lorenzo and Trastevere areas"). There were also two types of general answers similar in the cases of both Warsaw and Rome. Some skilled expatriates listed a number of places without any specific comment, while others said that they were unable to give a list of places. Especially some Italians in Warsaw, when asked about places to recommend to a friend, dismissed the question by saying, "I don't know," "No idea" or "To be honest, I'm not very fond of being a tour guide."

In the case of Rome, some Poles gave general answers that also avoided mentioning specific places: "Normally if someone comes for the first time, they already have their plans on what to visit" or "I would advise them to walk and to keep their eyes wide open." Finally, there were places specific to each city. For Rome, it was the Colosseum ("it is the symbol of 
Rome"), while for Warsaw Italians recommended museums, which are new, interactive and attract large audiences ("I would visit the main museums, such as the new museum of Chopin, the museum of World War II and the new museum of technology"). On the one hand, in Rome there was the ancient, unchanging monument, the city's icon-symbol; on the other hand, in Warsaw, there were modern, technological museum complexes.

No particular illustrative variable was relevant for the "10, 100, 1000 places" cluster because it gathered the replies of many different types of interviewees, both Italian and Polish. As the name of the cluster implies, there was a sense of infinity when participants spoke of places in Rome and Warsaw. Any list given to a friend would always remain open; there was no strict itinerary that had to be respected. According to the interviewees, the choice was also very personal and depended on what a person considered important or fascinating, as summarized by one of the subjects: "I would advise them to walk and to keep eyes wide open."

The last cluster, graphically paired with cluster 3 because both concerned places (see the dendrogram), was dedicated entirely to Rome. Polish skilled expatriates shared their personal favorites and explained why certain places in the Eternal City had especial value for them, impressed by the history, art, and religion evident throughout Rome. When Polish skilled expatriates spoke about places in Rome, they mentioned a wide variety, as if to state, "Everything says Rome!" First, many of the places mentioned can be classified as religious. The Vatican certainly played a very important role, not only for spiritual reasons but also for historical and artistic ones ("the Vatican Gardens but see the Vatican Museums"). Churches and basilicas were also greatly appreciated by Polish skilled expatriates in Rome, who directed attention to masterpieces of art displayed in many of them, such as Santa Maria sopra Minerva, "with the paintings of Filippino Lippi inside." However, the interviewees recommended not exaggerating the number of churches visited in a day: "I would recommend not going to ten churches a day, because you will not remember everything, but maybe choosing one or two and really studying their history and art." Reading the abovementioned lengthy books on the city written by Polish authors had probably influenced this approach to churches in Rome (very different from quick tours, such as "Rome in a Day"). It seems that Polish residents definitely preferred quality to quantity; they savored multiple aspects of one place instead of touring as many places as possible. In regard to religious aspects of Rome, the Polish interviewees also mentioned the catacombs, given their importance for the history of Christianity ("I like catacombs also, because I think that you can learn a lot about how life was when the first Christians were there").

Second, the Polish skilled expatriates in Rome appreciated the historic center of the city, with its characteristic places remarkable for their architecture, such as the Trevi Fountain, the Spanish Steps, Piazza del Popolo, Piazza della Minerva, etc. These well-preserved treasures of more recent history appealed to the romantic spirit, to the appreciation of art and architecture. In fact, as one of the interviewees put it, Rome is full of places of this kind, and 
one visit is certainly not enough, so "in the end I would definitely recommend visiting, seeing Trevi Fountain, throwing a coin under one's left arm, in order to come back and see all the remaining things." Third, contrary to the monuments of more recent history, the Polish interviewees had mixed feelings about the ancient Roman places. On the one hand, some said, 'I don't like seeing only ruins, just standing like that, like Forum Romanum doesn't tell me much because I know too little about it." On the other hand, some mentioned many monuments of ancient Roman history, especially the Colosseum.

Common to all the above types of places was the overwhelming feeling that the participants wanted to learn and remember as much as possible, finding out every detail on each place. Certainly, life is too short to do it all, but they enjoyed attempting to do so, enriched by solid reading and conversations with more knowledgeable persons ("who know so much about the history of the city and can tell you so many interesting things about it"). The illustrative variables for the cluster "Everything say Rome!" included the age group of young adults, resident in Rome from one to five years, Poles, academics, females, and singles. Especially significant for the approach to the places in Rome was the subjects' profession, which probably explained their love of learning about the city, studying its curiosities and details. Young adults, as singles, may have more time to dedicate to learning about the city, freely exploring it, and reading about it. Finally, the period from one to five years is probably the right amount of time to understand that much has already been seen but much more remains to be discovered and rediscovered.

Overall, Warsaw and Rome were much more different than similar. Both the findings of the questionnaires and the interviews demonstrate that the origin of this difference was the approach to each city. Even though the Italian skilled expatriates in Warsaw and the Polish skilled expatriates in Rome were asked the same questions about each city, each group highlighted completely different aspects. As demonstrated above, while the Italians focused on recent history, ideology, and values in Warsaw (in short, its people), the Poles mainly considered the physical surroundings in Rome.

\section{CONCLUSIONS}

The circulation of skilled expatriates around Europe is a complex and dynamic phenomenon, difficult to capture with statistics (Mahroum, 2001). The media discourse on mobility into Italy and Poland often functions to reproduce and maintain a racist interpretation of intergroup relations, especially in the light of the "refugee crisis" (Montali, Riva, Frigerio, \& Mele, 2013; Krzyżanowski, 2017). However, in spite of the fact that, for the above reason, in everyday speech, the term 'immigrant' often carries a negative meaning, and in general, the communities of skilled expatriates do not think of themselves as migrants, mobility embraces every category of people (Koser \& Salt, 1997). While investigating the participants' place-identity and cross-social representations of their native and new home- 
city, our research also explored the motivation and temporary/permanent aspects of mobility by going beyond purely statistical information (Castro, 2006). In line with the approach of city-as-context (Brettell, 2003), Rome and Warsaw constitute contexts where skilled expatriates' adaptation processes occur among determined communities (Van Kerckem, Van de Putte, \& Stevens, 2013).

In the light of the theoretical perspective proposed earlier in the paper (Moscovici, 1970) skilled mobility in Italy and Poland is heavily marked by a sort of double identity and double life on various levels: practical (possessing houses, cars, and other goods in both Italy and Poland), professional (skilled expatriates often built careers on their bilingualism, doing cross-national research, representing one country in another, etc.), social (having friends and/or relatives in both Italy and Poland), emotional (strong feelings about current situations in both countries) and often spiritual (Polish skilled expatriates strongly feel Rome to be a privileged place, while Italian skilled expatriates are moved by the Polish religiosity that they observe in Warsaw). This is a good example of transnationalism in the contemporary scenario of superdiversity (Goodson \& Grzymala-Kazlowska, 2017). However, we have found no evidence of situating our results within the transnational feminism related to postcolonialism (Pio \& Essers, 2014), probably due to the medium to high status of the participants as skilled professionals. This integrates well with the theoretical developments of social representations and social positioning (Elejabarrieta, 1994).

Especially concerning the superdiversity dimension of space/place, the conceptual framework of the theory of social representations appears as a heuristic tool for the comprehension of settings (Fuhrer, 1990; de Rosa, 2013b). It allows for a multi-dimensional study of the complexity of the dynamic phenomenon of mobility of skilled expatriates, as well as the meanings of places in an urban context. The theory of social representations fits into the urban culturalist perspective, in the domain of research on images and representations of the city (Borer, 2006). We hope that we have been able to show that the place-identity and social representations of the cities were related to the interviewees' motivations and visions of their personal transnational experience. In line with de Rosa's (2013a, p. 316) definition of place-identity as a "substructure of self-identity characterized by clusters of cognitions, memories and affects concerning places experienced by the individual," this active personal construction, deriving from day-to-day experiences of the physical environment is also related to individual mobility motivations and patterns.

By integrating the transnational approach to mobility in the contemporary scenario of superdiversity (Goodson \& Grzymala-Kazlowska, 2017) with the theoretical framework of social representations of cities in the light of place-identity, this paper adds to the body of literature on the experiences of skilled expatriates in Europe. It demonstrates that the complex perception of experienced urban contexts includes interpersonal relations with aesthetically stimulating physical environment, interwoven with cultural reflections that have to do with motivations behind the transnational lifestyle. 


\section{REFERENCES}

Ackers, L. (2005). Moving People and Knowledge: Scientific Mobility in the European Union. International Migration, 43(5), 99-131. doi: http://doi.org/dr7fq8

Andreouli, E., \& Howarth, C. (2013). National Identity, Citizenship and Immigration: Putting Identity in Context. Journal for the Theory of Social Behaviour, 43(3), 361-382. doi: http://doi.org/f49sjp

Anguelovski, I. (2013). From Environmental Trauma to Safe Haven: Place Attachment and Place Remaking in Three Marginalized Neighborhoods of Barcelona, Boston, and Havana. City \& Community, 12(3), 211-237. doi: http://doi.org/f49sjp

Balaz, V., Williams, A. M., \& Kollar, D. (2004). Temporary versus Permanent Youth Brain Drain: Economic Implications. International Migration, 42(4), 3-32. doi: http://doi.org/dz3jxv

Beauregard, R. A. (2003). City of Superlatives. City \& Community, 2(3), 183-199. doi: http://doi.org/c58g5w

Boccagni, P. (2013). Migration and The Family Transformations It "Leaves Behind": A Critical View from Ecuador. The Latin Americanist, 57(4), 3-24. doi: http://doi.org/dw3t

Bonnes, M., \& Secchiaroli, G. (1995). Social representations of place in the urban environment: Some research results. In M. Bonnes \& G. Secchiaroli (Eds.), Environmental Psychology: A Psycho-social Introduction, (pp. 180-185). London: Sage.

Borer, M. I. (2006). The Location of Culture: The Urban Culturalist Perspective. City \& Community, 5(2), 173-197. doi: http://doi.org/frfw76

Breakwell, G. (2010). Resisting Representations and Identity Processes. Papers on Social Representations, 19, 1-11.

Brettell, C. B. (2003). Bringing the City Back in Cities as Contexts for Immigrant Incorporation. In N. Foner (Ed.), American Arrivals: Anthropology Engages the New Immigration, (pp. 163-95). Santa Fe, NM: School of American Research Press.

Calas, M., \& Smircich, L. (2006). 'From the "woman's point of view” ten years later'. In S. Clegg, C. Hardy, T. Lawrence, \& W. Nord (Eds.), The Sage Handbook of Organization Studies, (pp. 284-346). London: Sage.

Castro, P. (2006). Applying social psychology to the study of environmental concern and environmental worldviews: contributions from the social representations approach. Journal of Community and Applied Psychology, 16(4), 247-266. doi: http://doi.org/c6h8sm 
Collins, F. L., \& Shubin, S. (2015). Migrant times beyond the life course: The temporalities of foreign English teachers in South Korea. Geoforum, 62, 96-104.

Cresswell, T. (2014). Place: An Introduction. Sussex, UK: John Wiley \& Sons.

Cresswell, T. (2016). Gendered mobilities. London: Routledge.

Cranston, S. (2017). Expatriate as a 'Good 'Migrant: Thinking Through Skilled International Migrant Categories. Population, Space and Place, 23(6), 1-12. doi: ttp://doi.org/gcpwcm

De Rosa, A. S. (1993). Social Representations and Attitudes: Problems of Coherence between the Theoretical Definition and Procedure of Research. Papers on Social Representations, 2(3), 1-15.

De Rosa, A. S. (1995). Psicología del turismo: per una psicologia sociale dell'ambiente applicata. In B. Zani (Ed.), Le dimensioni della psicologia sociale, (pp. 153-186). Bologna: Il Mulino.

De Rosa, A. S. (1997). Turisti di sei nazionalità per la prima volta nella 'città eterna': 'placeidentity' e rappresentazioni sociali di Roma e del suo centro storico. In A. Nenci (Ed.), Conoscere e rappresentare la città, (pp. 149-214). Padua: Ed. Cedam.

De Rosa, A. S. (2013a). Place-identity and Social Representations of Historic Capital Cities: Rome Through the Eyes of first Visitors from six Countries. In A. S. de Rosa (Ed.), Social Representations in the 'Social Arena', (pp. 311-381). New York/London: Routledge.

De Rosa, A. S. (2013b). Taking Stock: A theory with more than half a century of history. In A. S. de Rosa (Ed.), Social Representations in the 'Social Arena', (pp. 1-63). New York/London: Routledge.

De Rosa, A. S. (2015). The So.Re.Com. A.S. de Rosa @-library for Documentation, Networking and Training. In M. Khosrow-Pour (Ed.), Encyclopedia of Information Science and Technology, (pp. 260-271). Hershey, Pennsylvania: IGI Global. doi: http://doi.org/dw3w

De Rosa, A. S., \& d'Ambrosio, M. (2011). Universi semantici tra luoghi immaginati e luoghi esperti: first visitor italiani in sei capitali europee. Turismo e Psicologia, 1, 429-450.

De Rosa, A. S., Antonelli, T., \& Calogero, A. (1995). Roma immaginata e Roma vissuta nelle rappresentazioni sociali di turisti di sei nazionalità. In V. Cinanni, R. Virdi, \& G. Fumai (Eds.), Ambiente, Salute, Cultura, (pp. 137-155). Rome: Kappa.

De Rosa, A. S., Bocci, E., \& Picone, M. (2013). E-branding and institutional websites: the "visiting card" of the municipalities of Rome and Paris. In A. Kapoor \& C. Kulshrestha (Eds.), Branding and Sustainable Competitive Advantage: Building Virtual Presence, (pp. 207-247). Hershey, Pennsylvania: IGI Global. doi: http://doi.org/dw3x 
De Rosa, A. S., \& Bocci, E. (2014). Place @-Branding and European Capitals:"city visiting cards" via municipal websites, virtual tours of significant places flying with Google Earth, and conversational exchanges about city-places experienced/imagined via social networks. In A. Kapoor \& C. Kulshrestha (Eds.), Dynamics of Competitive Advantage and Consumer Perception in Social Marketing, (pp. 126-168). Hershey, Pennsylvania: IGI Global.

Elejabarrieta, F. (1994). Social positioning: a way to link social identity and social representations. Social Science Information, 33(2), 241-53. doi: http://doi.org/dxsk9d

Fazito, D., \& Soares, W. (2015). The Industry of Illegal Migration: Social Network Analysis of the Brazil-US Migration System. International Migration, 52(6), 183-204. doi: http://doi.org/f76cqz

Fuhrer, U. (1990). Bridging the Ecological-Psychological Gap. Behavioral Settings as Interfaces. Environment and Behavior, 22(4), 518-37.

Goodson, L., \& Grzymala-Kazlowska, A. (2017). Researching Migration in a Superdiverse Society: Challenges, Methods, Concerns and Promises. Sociological Research Online, 22(1), 1-13.

Goss, J., \& Lindquist, B. (1995). Conceptualizing International Labor Migration: A Structuration Perspective. International Migration Review, 29(2), 317-351.

Guan, J., \& Liu, L. (2014). Recasting Stigma as a Dialogical Concept: A Case Study of Rural-to-Urban Migrants in China. Journal of Community \& Applied Social Psychology 24, 75-85. doi: http://doi.org/f5vxfn

Hodos, J. (2007). Globalization and the Concept of the Second City. City \& Community, 6, 315-333. doi: http://doi.org/cz3vkk

Hubbard, P. (1996). Urban Design and City Regeneration: Social Representation of Entrepreneurial Landscapes. Urban Studies, 33, 1441-1461.

Iglicka, K., \& Ziolek-Skrzypczak, M. (2010). EU Membership Highlights Poland's Migration Challenges. Migration Information Source, September. Retrieved from http://www.migrationinformation.org/Profiles/display.cfm?ID=800

Iredale, R. (2001). The Migration of Professionals: Theories and Typologies. International Migration, 39(5), 7-26. doi: https://doi.org/10.1111/1468-2435.00169

Janz, B. (2005). Walls and Borders: The Range of Place. City \& Community, 4(1), 87-94. doi: http://doi.org/dritmq

Jodelet, D. (1987). The study of people-environment relations in France. In D. Stokols \& I. Altman (Eds.), Handbook of Environmental Psychology, (pp. 1171-1193). New York: Wiley. 
$22 \begin{aligned} & \text { Intra-European Mobility of Skilled Expatriates and Place-Identity: Interwoven Social Representations... } \\ & \text { Silvada de Rosa, A., \& Dryjanska, L. }\end{aligned}$

Jodelet, D. (2008). Social Representations: The Beautiful Invention. Journal for the Theory of Social Behaviour, 38(4), 411-430. doi: http://doi.org/cv7rr8

Kempny, M. (2013). Tales from the borderlands: Polish migrants' representations of the Northern Irish conflict in Belfast. Space and Culture, 16(4), 435-446. doi: http://doi.org/dw32

Khoo, S.-E., Graeme, H., \& McDonald, P. (2008). Which Skilled Temporary Migrants Become Permanent Residents and Why? International Migration Review, 42(1), 193226. doi: http://doi.org/ffzhgq

Khoo, S.-E., McDonald, P., Voigt-Graf, C., \& Graeme H. (2007). A Global Labor Market: Factors Motivating the Sponsorship and Temporary Migration of Skilled workers to Australia. International Migration Review, 41(2), 480-510. doi: http://doi.org/dn4gt3

King, R. (2002). Towards a New Map of European Migration. International Journal of Population Geography, 8(2), 89-106. doi: http://doi.org/bt6cj9

Koser, K., \& Salt, J. (1997). The Geography of Highly Skilled International Migration. International Journal of Population Geography, 3(4), 285-303.

Kraly, E. P., \& Hirschman, C. (1994). Immigrants, Cities, and Opportunities: Some Historical Insights from Social Demography. Center for Migration Studies special issues 11(1), 16-45. doi: http://doi.org/dw33

Krzyżanowski, M. (2017). Discursive Shifts in Ethno-Nationalist Politics: On Politicization and Mediatization of the "Refugee Crisis" in Poland. Journal of Immigrant \& Refugee Studies, 16(1-2), 1-21.

Kunz, S. (2016). Privileged mobilities: Locating the expatriate in migration scholarship. Geography Compass, 10(3), 89-101.

Mahroum, S. (2001). Europe and the Immigration of Highly Skilled Labour. International Migration, 39(5), 27-43. doi: http://doi.org/b7wm7p

Marada, R. (2011). Ethnization-Migration-Identity and Urban Places. Paper presented at the 17th International Summer School on Social Representations and Communication. Rome, Italy.

Massey, D. S., Arango, J., Graeme, H., Kouaouci, A., Pellegrino, A., \& Taylor, E. (1993). Theories of International Migration: A Review and Appraisal. Population and Development Review, 19(3), 431-466.

McHenry, J. E., \& Welch, D. E. (2018). Entrepreneurs and internationalization: A study of Western immigrants in an emerging market. International Business Review, 27(1), 93101. 
McNulty, Y., \& Selmer, J. (2017). Research Handbook of Expatriates. Cheltenham, UK: Edward Elgar Publishing.

Montali, L., Riva, P., Frigerio, A., \& Mele, S. (2013). Discourse and politics of migration in Italy: The production and reproduction of ethnic dominance and exclusion. Journal of Language and Politics, 25, 226-250.

Mortimer, J. T., \& Moen, P. (2016). The changing social construction of age and the life course: Precarious identity and enactment of "early" and "encore" Stages of Adulthood. In M. Shanahan, J. Mortimer, \& M. Kirkpatrick Johnson (Eds.), Handbook of the life course, (pp. 111-129). Heidelberg, Germany: Springer Cham.

Moscovici, S. (1961). La Psychanalyse, son Image et son Public. Étude sur la representation sociale de la psychoanalyse. Paris: Presses Universitaires de France.

Moscovici, S. (1970). Preface. In D. Jodelet, J. Viet, \& P. Besnard (Eds.), La Psychologie Sociale, Une Discipline en Mouvement, (pp. 13-64). Paris-La Haye: Mouton.

Orr, E., Mana, A., \& Mana, Y. (2003). Immigrant identity of Israeli adolescents from Ethiopia and the former USSR: culture-specific principles of organization. European Journal of Social Psychology, 33(1), 71-92. doi: http://doi.org/dx5k5w

Paiva, D. (2016). Collapsed rhythms: The impact of urban change in the everyday life of elders. Space and Culture, 19(4), 345-360. doi: http://doi.org/dw34

Peixoto, J. (2001). Migration and Policies in the European Union: Highly Skilled Mobility, Free Movement of Labour and Recognition of Diplomas. International Migration, 39(1), 33-61. doi: http://doi.org/bdjs5t

Pellegrino, A. (2001). Trends in Latin American Skilled Migration: "Brain Drain" or "Brain Exchange"? International Migration, 39(5), 111-132. doi: http://doi.org/fb46ts

Pio, E., \& Essers, C. (2014). Professional migrant women decentring otherness: A transnational perspective. British Journal of Management, 25(2), 252-265.

Polson, E. (2015). A gateway to the global city: Mobile place-making practices by expats. New Media \& Society, 17(4), 629-645.

Prickett, P. J. (2014). Contextualizing from Within: Perceptions of Physical Disorder in a South-Central L.A. African American Mosque. City \& Community, 13, 214-232. doi: http://doi.org/fhqwg3

Rateau, P., Moliner, P., Guimelli, C., \& Abric, J.C. (2011). Social Representation Theory. In P. A. M. Van Lange, A. W. Kruglanski, \& E. T. Higgins (Eds.), Handbook of Theories of Social Psychology Vol. 2, (pp. 477-498). London/Thousand Oaks, CA: Sage. 
Tilly, C. (1990). Transplanted networks. In V. Yans-McLaughlin (Ed.), Immigration Reconsidered. History, Sociology, and Politics, (pp. 79-95). New York: Oxford Univesity Press. doi: http://doi.org/fhqwg3

Ufficio Centrale di Statistica (2016). Anagrafe degli italiani residenti all'estero. Retrieved from

http://ucs.interno.gov.it/FILES/AllegatiPag/1263/TER_INT_00041_DAIT_AIRE_ed_ 2016.pdf

Van Kerckem, K., Van de Putte, B., \& Stevens, P. (2013). On Becoming “Too Belgian”: A Comparative Study of Ethnic Conformity Pressure through the City-as-Context Approach. City \& Community, 12, 335-360. doi: http://doi.org/f5ppmt

Van Riemsdijk, M. (2016). Homogenizing the City. In M. Riemsdijk \& Q. Wang (Ed.), Themes, Gaps, and Opportunities for Rethinking International Skilled Migration. Rethinking International Skilled Migration, (pp. 173-193). London, UK: Routledge.

Wise, A. (2016). Mobilising Sentiment for Multiplicity. In J. Darling \& H.F. Wilson (Eds.), Encountering the City: Urban Encounters from Accra to New York, (pp. 25-44). London: Routledge.

Wladyka, D., \& Morén-Alegret, R. (2014). Polish immigration in Barcelona: The Sagrada Familia neighbourhood as an arena for interaction. International Migration, 52(1), 146164.

Zubrzycki, J. (1953). Emigration from Poland in the Nineteenth and Twentieth Centuries. Population Studies, 6(3), 248-272. Retrieved from http://www.jstor.org/stable/2172378 